\title{
PENGATURAN TERHADAP ADVOKAT ASING YANG BERACARA DI INDONESIA DITINJAU DARI UNDANG- UNDANG NO 18 TAHUN 2003 TENTANG ADVOKAT
}

\author{
Oleh \\ Putu Ngurah Bagus Robin Cahaya Putra ${ }^{1}$ \\ Putu Tuni Cakabawa Landra ${ }^{2}$
}

\begin{abstract}
Advocate profession has an important role for law enforcement in the State Indonesia. Advocate profession is currently being confused by their international agreements MEA and GATS in the State Indonesia with other ASEAN countries, one of which regulates the profession of advocate, who make arrangements in Law No. 18 Year 2003 concerning Advocates become unclear, especially to Article 23 of Law No. 18 Year 2003 concerning Advocates stipulates that foreign lawyers are prohibited in court proceedings, practice andor open a legal services office or representative in Indonesia. Based on these two issues can be raised is how the setting of norms on foreign lawyers who want to proceedings in Indonesia in relation with the MEA and how preparedness advocates Indonesia in the era of globalization and asean economic community. Types of Research in this paper is a normative legal research conducted through an analysis of the norms of the legislation. The results of this study can be explained procedural authority of a foreign advocate in the State Indonesia obstructed by Article 23 of Law No. 18 Year 2003 is causing confusion when they see their International agreements that have been agreed State Indonesia on MEA and GATS governing trade in services within international scope. The setting of an ideal advocate for the State of Indonesia as not to be confused with the International agreement both GATS and the MEA is the revision of Law No.18 of 2003 concerning Advocates, in particular on Article 23 in order to be able to advocate foreign proceedings in Indonesia is on condition and stages which must be passed so that later obtained the minutes of the oath from the high court and a member's card PERADI advocate of advocate organizations. As for the readiness advocates in Indonesia in the face of this MEA has readiness much when compared with foreign advocates for excess advocates Indonesia is knowing the legal regulations in Indonesia and the Indonesian communications were good compared to foreign lawyers who want proceedings in Indonesia.
\end{abstract}

Keywords: Advocates profession, Foreign advocates, MEA (Asean Economic Community).

\footnotetext{
1 Program Studi Magister Ilmu Hukum, Fakultas Hukum Universitas Udayana, Bali e-mail: bagusrobin41@yahoo.com.

2 Fakultas Hukum Universitas Udayana, Bali email: putusakabawa@yahoo.com.
} 


\begin{abstract}
Abstrak
Profesi advokat mempunyai peranan penting bagi penegakan hukum di Negara Indonesia. Profesi advokat saat ini sedang dibingungkan oleh adanya kesepakatan internasional MEA dan GATS di Negara Indonesia dengan Negara Asean lainya yang salah satunya mengatur tentang profesi advokat, yang membuat pengaturan dalam Undang-Undang No 18 Tahun 2003 tentang Advokat menjadi rancu, khususnya pada Pasal 23 Undang-Undang No. 18 Tahun 2003 tentang Advokat menetapkan bahwa advokat asing dilarang beracara di pengadilan, berpraktik dan/ atau membuka kantor jasa hukum atau perwakilannya di Indonesia. Berdasarkan hal tersebut dapat diangkat dua permasalahan yaitu bagaimana pengaturan norma tentang advokat asing yang ingin beracara di Indonesia dalam kaitannya dengan MEA dan bagaimana kesiapan advokat Indonesia dalam menghadapi era globalisasi dan masyarakat ekonomi asean. Jenis Penelitian pada penulisan ini adalah penelitian hukum normatif yang dilakukan melalui analisis terhadap norma dalam peraturan perundang-undangan. Hasil penelitian ini dapat dijelaskan kewenangan beracara dari advokat asing di Negara Indonesia dihalangi oleh Pasal 23 Undang-Undang No. 18 Tahun 2003 tersebut sehingga menimbulkan kerancuan bila melihat adanya kesepakatan Internasional yang telah disepakati Negara Indonesia tentang MEA dan GATS yang mengatur tentang perdagangan jasa dalam ruang lingkup internasional. Pengaturan tentang advokat yang ideal untuk Negara Indonesia karena agar tidak rancu dengan perjanjian internasional baik GATS maupun MEA adalah dengan merevisi Undang-Undang No.18 Tahun 2003 tentang Advokat, khususnya pada Pasal 23 agar advokat Asing agar dapat beracara di Indonesia tentunya dengan syarat dan tahapan yang harus dilalui sehingga nantinya memperoleh berita acara sumpah dari pengadilan tinggi dan memiliki kartu anggota advokat dari organisasi advokat PERADI. Sedangkan untuk kesiapan advokat di Indonesia dalam menghadapi MEA ini memiliki kesiapan yang jauh jika dibandingkan dengan advokat asing karena kelebihan advokat Indonesia adalah mengetahui regulasi hukum di Indonesia dan komunikasi bahasa Indonesia yang baik dibandingkan dengan advokat asing yang hendak beracara di Indonesia.
\end{abstract}

\title{
Kata Kunci: Profesi Advokat, Advokat Asing, MEA (Masyarakat Ekonomi Asean).
}

\section{PENDAHULUAN}

Negara Indonesia merupakan Negara hukum hal ini telah ditetapkan pada Undang-Undang Dasar 1945 Pasal 1 ayat (3). Maka dari itu di Negara Indonesia telah memiliki banyak peraturan perundangundangan baik itu hasil produk nasional maupun produk dari adanya kesepakatan dengan Negara tetangga
(Internasional). Hal ini berarti bahwa tidak ada orang yang berada di atas hukum, baik pejabat maupun warga negara biasa berkewajiban untuk mentaati hukum. ${ }^{3}$

Profesi advokat atau pengacara dalam dunia peradilan mempunyai peranan penting bagi penegakan hukum

3 Philipus M. Hadjon, 2007, Perlindungan Hukum Bagi Rakyat Indonesia, Peradaban, hlm.75. 
di Negara Indonesia. Profesi advokat di Indonesia adalah sebuah profesi yang terhormat dan dihormati di peradilan di Indonesia (officium nobile), maka dari itu pengaturan tentang advokat telah ditetapkan dan diundangkan pada Undang-Undang No. 18 tahun 2003 tentang Advokat. Profesi advokat di Negara Indonesia mempunyai satu wadah organisasi yaitu bernama PERADI (Perhimpunan Advokat Indonesia). Profesi advokat diketahui menjadi suatu profesi yang digemari oleh masyarakat karena banyak dari para advokat memiliki taraf ekonomi yang bagus, hal ini sesuai pernyataan dari Bernard dan Kostecki modern economies are service economies (ekonomi modern adalah ekonomi jasa). ${ }^{4}$ Perekrutan anggota advokat di Indonesia yang diselenggarakan oleh organisasi advokat yaitu PERADI harus melewati beberapa tahapan. Adapun tahapan dari seseorang untuk menjadi advokat di Indonesia yaitu:

1. Berkebangsaan Negara Republik Indonesia

2. Harus lulus dari fakultas hukum

3. Harus lulus pendidikan khusus profesi advokat yang diadakan oleh organisasi advokat (PERADI)

4. Harus lulus dari ujian advokat yang diadakan oleh organisasi advokat yaitu PERADI

4 Bernard, M Hoekman dan Michel Koestecki, 1995, The Political Economy of thr word Trading System From Gatt to WTO, oxford, oxford university press. hlm.127.
5. Setelah lulus ujian advokat para calon advokat diharuskan magang selama 2 (dua) tahun di kantor advokat yang memiliki pengalaman 7 (tujuh) tahun beracara hukum

6. Setelah magang dikantor advokat para calon advokat diwajibkan mengikutipenyumpahan advokat di Pengadilan Tinggi untuk dilantik dan disumpah menjadi seorang advokat.

Profesi advokat dapat dikategorikan bagian dari perdagangan jasa. Perdagangan jasa ini telah diatur dan disepakati oleh negara-negara ASEAN termasuk Negara Indonesia. Pemikiran tentang liberalisasi perdagangan dan jasa di wilayah negara-negara ASEAN ini bermula dari hasil pertemuan negara-negara ASEAN tahun 1995 di Bangkok, Thailand. Dalam pertemuan tersebut melahirkan kesepakatan yang disebut Asean Framework Agreement on Service (AFAS) sebagai landasan dasar dari proses menuju liberalisasi perdagangan jasa di kawasan ASEAN. Melalui liberalisasi perdagangan bidang jasa, pertemuan negara-negara ASEAN telah mengesahkan AFAS pada KTT ke-5 ASEAN tanggal 15 Desember 1995 di Bangkok, Thailand yang bertujuan untuk meningkatkan daya saing para penyedia sektor jasa di negara-negara ASEAN itu sendiri. ${ }^{5}$

5 Dirjen Kerja Sama ASEAN Kementerian Luar Negeri Republik Indonesia, 2009, Integrasi Ekonomi ASEAN dibidang Jasa, Jakarta, hlm. 7. 
Adapun kesepakatan dunia internasional yang mengatur prinsip dasar dari aturan permainan dalam perdagangan internasional dihidang jasa yaitu terdapat dalam World Trade Organization (WTO). Kesepakatan tersebut tertuang dalam General Agreement Tarrif on Service (GATS). Pengaturan mengenai kerangka perjanjian GATS ini terdapat dalam Annex 1b dari Piagam WTO. Peraturan dalam Annex 1b tidak terpisahkan dari Piagam WTO itu sendiri. Negara Indonesia sebagai anggota Asean yang tunduk pada aturan internasional tersebuttelahsepakatpadaaturan-aturan internasional tentang perdagangan jasa. Pengaturan tentang perdagangan jasa dalam GATS ditetapkan dalam Pasal 1 ayat (1) peraturan tentang GATS yang menyatakan : "This Agreement applies to measures by member affecting trade in service". Pasal ini menjelaskan yang dimaksud dengan Trade in Service yaitu perdagangan jasa yang dilakukan melalui :

a. Jasa yang diberikan dari suatu wilayah negara lain (cross-border) contohnya jasa yang menggunakan media telekomunikasi.

b. Jasa yang diberikan ke wilayah negara pada suatu konsumen dari negara lain (consumption abroad) contohnya pariwisata (tourism).

c. Jasa yang diberikan melewati kehadiran badan usaha negara ke dalam wilayah negara lain (commercial presence) contohnya membuka kantor cabang bank asing.

d. Jasa yang diberikan warga negara kepada suatu negara ke dalam wilayah negara lain (presence of natural person) contohnya jasa konsultan, advokat dan akuntan. ${ }^{6}$

BerlakunyaMasyarakatEkonomi Asean (MEA) di Negara Indonesia, ternyata hal ini akan berpengaruh bagi masyarakat Indonesia, khususnya masyarakat yang berprofesi sebagai advokat. Pada dasarnya MEA memang harus dihadapi masyarakat di Indonesia, hal tersebut juga termasuk para advokat di Indonesia. Bahwa adapun permasalahan yang terjadi di dalam regulasi hukum Indonesia terhadap adanya advokat asing di Indonesia, dimana sesuai dengan adanya aturan internasional GATS dan MEA yang tersebut di atas dan telah di ratifikasi oleh Negara Indonesia yang menetapkan Undang-Undang No. 7 Tahun 1974 tentang Persetujuan Pembentukan Organisasi Perdagangan Dunia, maka keberadaan advokat asing seharusnya dapat beracara di peradilan Indonesia akan tetapi dalam aturan di Negara Indonesia yaitu dalam Pasal 23 ayat (1) Undang-Undang No. 18 Tahun 2003 tentang Advokat menetapkan bahwa advokat asing dilarang beracara di sidang pengadilan, berpraktik dan

6 Syahmin A.K, 2006, Hukum Dagang Internasional (Dalam Kerangka Studi Analitis), PT. Raja Grafindo Persada, Jakarta, hlm. 170-180. 
atau membuka kantor jasa hukum atau perwakilannya di Indonesia. Sementara Pasal 23 ayat (2) menyebutkan, kantor advokat dapat mempekerjakan advokat asing sebagai karyawan atau tenaga ahli dalam bidang hukum asing atas izin pemerintah dengan rekomendasi organisasi advokat. Hal tersebut mencerminkan tidak adanya dukungan terhadap aturan GATS dalam menyambut MEA ini. Padahal Indonesia sendiri telah sepakat dalam aturan GATS itu sendiri. Maka dari latar belakang masalah ini dapat diteliti dan dianalisa menjadi sebuah penelitian yang berjudul Pengaturan terhadap advokat asing yang beracara di Indonesia ditinjau dari undang-undang No. 8 Tahun 2003 tentang advokat dalam hubungannya dengan MEA. Adapun rumusan masalah yang diangkat dalam penelitian ini adalah

1. Bagaimana pengaturan yang berkenaan dengan advokat asing yang ingin beracara di Indonesia?

2. Bagaimana hak dan kewajiban Advokat asing dalam beracara di Negara Indonesia?

Dalam penulisan ini, peneliti akan menampilkan orisinalitas penyusunan jurnal yang berbeda dengan penelitian yang lainnya, antara lain sebagai berikut: pertama jurnal dari I Made Sari (Mahasiswa Universitas Udayana), berjudul "Persamaan Perlakuan Para Pihak Dalam Beracara di KPPU dalam
Perspektif Hukum Acara Peradilan Indonesia"7, kedua jurnal dari Maharani Roya (Mahasiswa Program Pasca Sarjana Universitas Brawijaya) yang berjudul "Implementasi Kewajiban Advokat Dalam Menjaga Rahasia Klien"8, ketiga jurnal dari Stela Delaros (Mahasiswa Fakultas Hukum Universitas Taman siswa Padang) yang berjudul "Liberalisasi Fee Advokat: Antara Perlindungan Dan Kompetisi terhadap Advokat Indonesia"9.

Adapun tujuan yang ingin dicapai dalam penelitian ini adalah pertama untuk mengetahui dan menganalisa pengaturan yang berkenaan dengan advokat asing yang ingin beracara di Negara Indonesia, kedua untuk

7 Sari, I Made. PERSAMAAN PERLAKUAN PARA PIHAK DALAM BERACARA DI KPPU DALAM PERSPEKTIF HUKUM ACARA PERADILAN INDONESIA. Jurnal Magister Hukum Udayana (Udayana Master Law Journal), vol. 5 no. 2 edisi juli 2016. $<$ https://ojs.unud.ac.id/index.php/jmhu/article/ view/22434>. Diakses tanggal 14 April 2017. doi:https://doi.org/10.24843/JMHU.2016.v05. i02.p12.

8 Ananta, Maharani Roya. "IMPLEMENTASI KEWAJIBAN ADVOKAT DALAM MENJAGA RAHASIA KLIEN (Studi di Kantor Advokat Jonifianto \& Partners, Lardi \& Partners, dan Kantor Sekretariat Dewan Kehormatan Daerah (DKD) PERADI Jawa Timur)." Jurnal Mahasiswa Fakultas Hukum 1.2 (2014). <https://hukum. studentjournal.ub.ac.id/index.php/hukum/ article/view/370> diakses tanggal 14 april 2017.

9 Delarosa, Stella. "Liberalisasi Fee Advokat: Antara Perlindungan Dan Kompetisi Terhadap Advokat Indonesia." Veritas et Justitia 2.2 (2016): 355. <http://journal.unpar.ac.id/index. $\mathrm{php} /$ veritas/article/view/2271 $>$ diakses tanggal 14 april 2017. doi: http://dx.doi.org/1025123/ vej.22. 
mengetahui dan menganalisa hak dan kewajiban advokat asing dalam beracara di Negara Indonesia.

\section{METODE PENELITIAN}

Metode penelitian ini mempergunakan jenis penelitian hukum normatif. Dipergunakannya jenis penelitian hukum normatif karena agar penelitian ini mengkaji permasalahan-permasalahan yang ada, untuk selanjutnya dibahas dengan kajian berdasarkan teoriteori hukum yang dikaitkan dengan peraturan perundang-undangan yang berlaku ke dalam praktek hukum. ${ }^{10}$ Penelitian hukum normatif ini memuat beberapa hal antara lain penelitian terhadap asas-asas hukum, penelitian terhadap sistematika hukum, penelitian terhadap taraf sinkronisasi hukum dalam arti vertikal maupun horizontal, perbandingan hukum dan sejarah hukum. ${ }^{11}$ Jenis pendekatan dalam penelitian ini memakai jenis pendekatan perundang-undangan yang berlaku di Indonesia.

\section{HASIL DAN PEMBAHASAN}

3.1 Mengetahui dan Menganalisa Pengaturan yang Berkenaan dengan Advokat Asing yang ingin Beracara di Indonesia

Bahwa posisi Advokat dalam dunia Perdagangan jasa internasional

10 Soerjono Soekanto,2006, Penelitian Hukum Normatif (Suatu Tinjauan Singkat), PT. Grafindo Persada, Jakarta, hlm.13.

11 H. Zainuddin, 2011, Metode Penelitian Hukum, Sinar Grafika, Jakarta, hlm. 25-30. adalah sangat penting, karenanya hal ini juga sudah diatur dalam ketentuan GATS yang mengatur tentang Perdagangan dibidang jasa yang didalamnya juga termasuk advokat. Maka dari itu sehubungan dengan MEA maka bukan tidak mungkin advokat di Indonesia harus bersaing dengan advokat asing, dan hal ini yang harus dilakukan oleh advokat di Indonesia ialah sangat harus mempersiapkan diri baik itu ilmu pengetahuan dibidang hukum juga harus mempelajari bahasa asing (bahasa inggris) hal ini di pandang perlu dalam rangka menyambut MEA yang dibuka pada akhir tahun 2015, karena itu pemerintah Indonesia juga harus mempersiapkan regulasi hukum yang tepat agar tidak terjadi ketidaksingkronan norma antara kesepakatan internasional dengan hukum di Indonesia. Ketidaksingkronan norma ini ditandai dengan adanya larangan terhadap advokat asing untuk beracara di peradilan Indonesia, hal ini tercantum di dalam Pasal 23 Undang-Undang No. 18 tahun 2003 tentang advokat diatur bahwa advokat asing dilarang beracara di sidang pengadilan, berpraktik dan/ atau membuka kantor jasa hukum atau perwakilannya di Indonesia. Advokat asing dapat dipekerjakan oleh kantor advokat (domestik) sebagai karyawan atau tenaga ahli dalam bidang hukum asing atas izin Pemerintah dengan rekomendasi organisasi advokat dengan disertai pembebanan kewajiban untuk memberikan jasa 
hukum secara cuma-cuma untuk suatu waktu tertentu kepada dunia pendidikan dan penelitian hukum. Adapun peraturan pelaksanaan secara komprehensif mengenai persyaratan dan tata cara mempekerjakan advokat asing serta kewajiban memberikan jasa hukum secara cuma-cuma kepada dunia pendidikan dan penelitian hukum saat ini diatur lebih lanjut berdasarkan Kepmenkumham RI Nomor M.11-HT.04.02 Tahun 2004. Dengan konstruksi hukum semacam ini maka advokat asing secara tegas dilarang untuk berpraktik dan/atau membuka kantor jasa hukum atau perwakilannya di Indonesia. Hal ini pada prinsipnya tidaklah bertentangan dengan pedoman International Bar Association (IBA), namun demikian tiap-tiap negara memiliki regulasinya masing-masing terkait advokat asing. Amerika Serikat misalnya mengatur bahwa advokat asing dari negara lain dapat berpraktik di Amerika Serikat apabila telah lulus dari ujian bar exam dan sama sekali tidak ada ketentuan di Amerika Serikat yang mengatur bahwa advokat yang berpraktik di Amerika Serikat haruslah berkewarganegaraan Amerika Serikat.

Jika kita bandingkan dengan Pasal 23 UU Advokat, maka rumusan Pasal 54 Undang-Undang tentang Advokat akan memungkinkan advokat asing untuk membuka perwakilan kantornya di Indonesia. Halinitentunya harus dicermati secara seksama oleh parapembentukundang-undangdengan mempertimbangkan segala aspek yang terkait antara lain aspek kedaulatan bangsa, aspek ekonomi, serta aspek supremasi dan implikasi hukum apabila memungkinkan advokat asing untuk membuka perwakilan kantornya di Indonesia. Hal yang paling terasa jika advokat asing dimungkinkan untuk membuka perwakilan kantornya di Indonesia adalah terjadinya liberalisasi sektor jasa advokat di Indonesia. Hal ini tentunya akan memiliki dampak yang signifikan bagi menurunnya pelayanan bagi para pencari keadilan (justitiabelen). Advokat asing (jika telah lulus ujian hukum nasional di Indonesia) tentunya akan kesulitan dalam memahami filosofi-filosofi hukum yang khas di Indonesia. Selain itu, jika advokat asing dimungkinkan untuk membuka perwakilan kantornya di Indonesia maka dalam hal pemerintah berhadapan dengan korporasi asing maka hampir dapat dipastikan korporasi asing tersebut akan menggunakan jasa perwakilan kantor advokat asing yang ada di Indonesia. Hal ini tentu akan membawa proses hukum menjadi bias karena akan dipengaruhi oleh kepentingankepentingan politik internasional, baik bilateral,regional,maupunmultilateral, sehingga berpotensi menghasilkan suatu putusan pengadilan (nasional) yang dipengaruhi oleh kondisi politik internasional.

Dalam konstruksi yuridis dan sosiologis di Indonesia, advokat dianggap sebagai suatu profesi yang 
mulia (officium nobile). Dengan diakuinyasecaraempirisbahwaadvokat merupakan sebuah profesi maka upaya yang dilakukan advokat dalam memberikan jasa hukum bagi para pencari keadilan (justitiabelen) terkait pula dengan hak asasi advokat untuk mengejar kebahagiaan (memperoleh penghasilan/honorarium), meskipun dalam mengejar kebahagiaannya itu, advokat harus tetap menjaga kemuliaan profesinya.

Dalam Pasal 27 ayat (2) UUD 1945 juga diatur bahwa hak atas pekerjaan dan penghidupan yang layak bagi kemanusiaan hanya diperuntukkan bagi "Warga Negara", bukan bagi "Setiap Orang", sehingga hak konstitusional atas pekerjaan dan penghidupan yang layak bagi kemanusiaan, khususnya dalam memilih profesi sebagai advokat hanya diperuntukkan bagi warga negara (Indonesia). Pihak asing tidak dapat dengan bebas menikmati hak atas pekerjaan dan penghidupan yang layak bagi kemanusiaan di Indonesia, sehingga dalam hal pihak asing merasa perlu untuk melakukan pekerjaan dan penghidupan yang layak bagi kemanusiaan di Indonesia maka mereka harus tunduk pada peraturan perundang-undangan yang berada di bawah UUD 1945, termasuk undangundang advokat. Pihakasing tidak dapat mendalilkan bahwa pembatasan hak atas pekerjaan dan penghidupan yang layak bagi kemanusiaan di Indonesia yang diatur dalam UU Advokat bertentangan dengan UUD 1945 karena dalam perspektif konstitusi, hak atas pekerjaan dan penghidupan yang layak bagi kemanusiaan hanya diperuntukkan bagi "warga Negara", bukan bagi "Setiap orang". Hal ini merupakan salah satu implementasi dari tujuan pembentukan suatu Pemerintah Indonesia sebagaimana yang dicantumkan dalam Alinea keIV Pembukaan UUD 1945 yakni “... melindungi segenap bangsa Indonesia dan seluruh tumpah darah Indonesia dan untuk memajukan kesejahteraan umum...". Pengaturan dan pembatasan hak advokat asing untuk dapat berpraktik dan/atau membuka kantor jasa hukum atau perwakilannya di Indonesia kami pandang masih diperlukan untuk melindungi eksistensi dan pemberdayaan peran advokat domestik serta guna menghindari adanya praktik liberalisasi jasa advokat yang akan bersifat kontra produktif dengan terjaminnya kualitas pelayanan bagi masyarakat dalam memperoleh kepastian hukum dan keadilan.

\subsection{Hak dan Kewajiban Advokat Asing dalam Beracara di Negara Indonesia.}

Profesi advokat merupakan suatu profesi yang memberikan penghasilan yang cukup besar, maka dari itu profesi advokatmerupakan profesi yang sangat diminati oleh kalangan mahasiswa hukum. Profesi advocat merupakan profesi yang memberikan suatu jasa dibidang hukum kepada masyarakat 
baik didalam pengadilan (litigasi) maupun diluar pengadilan (Non Litigasi). Dalam upaya menciptakan prinsip-prinsip negara hukum dalam kehidupan bermasyarakat berbangsa, dan bernegara, maka peran advokat sebagai profesi yang bebas, mandiri, bertanggung jawab dan terhormat, adalah sesuatu yang penting, disamping lembaga dan instansi penegak hukum seperti Kepolisian dan Kejaksaan.

Advokat pada saat ini telah diatur dalam Undang-Undang Nomor 18 Tahun 2003 tentang Advokat. Pada Pasal 1 ayat (1) undang-undang advokat, telah ditentukan bahwa: "Advokat adalah orang yang berprofesi memberi jasa hukum, baik di dalam maupun di luar pengadilan yang telah memenuhi persyaratan berdasarkan ketentuan dalam undang-undang ini". Pada Pasal 1 ayat (2) undang-undang, ditentukan pula bahwa: "Jasa hukum merupakan jasa yang diberikan advokat berupa memberikan konsultasi hukum, bantuan hukum, menjalankan kuasa, mewakili, mendampingi, membela, dan melakukan tindakan hukum lain untuk kepentingan hukum klien". Melewati jasa hukum yang diberikan oleh advokat dalam menjalankan tugas profesinya demi tegaknya keadilan berdasarkan hukum untuk kepentingan masyarakat yang mencari keadilan, hal ini termasuk juga usaha dalam memberdayakan masyarakat dalam menyadari hak-hak fundamental mereka di depan hukum.
Advokat merupakan salah satu unsur sistem peradilan dan salah satu pilar dalam menegakkan supremasi hukum dan Hak Asasi Manusia. Selain dalam proses peradilan, peran advokat juga terlihat di jalur profesi di luar pengadilan (non litigasi). Kebutuhan jasa hukum seorang advokat di luar proses peradilan (non litigasi) sekarang semakin meningkat, dengan berkembangnya kebutuhan hukum di dalam masyarakat terutama dalam memasuki era kehidupan yang semakin terbuka dalam interaksi antar bangsa. Advokat sebagai profesi yang mandiri, bebas, dan bertanggung jawab di dalam menegakkan hukum dilindungi dan dijamin pemerintah dengan undang-undang advokat di dalam menyelenggarakan upaya penegakan supremasi hukum. Seseorang dapat diangkat sebagai advokat merupakan seseorang yang telah lulus sarjana hukum dan telah mengikuti pendidikan khusus profesi advokat dan ujian advokat yang dilaksanakan oleh Organisasi Advokat PERADI (Perhimpunan Advokat Indonesia).

Indonesia merupakan negara hukum yang berdasarkan Pancasila dan Undang-Undang Dasar Negara Kesatuan Republik Indonesia Tahun 1945 bertujuan menciptakan tata kehidupan bangsayang tertib, tenteram, sejahtera, aman, dan berkeadilan. Kekuasaan kehakiman yang terbebas dari campur tangan dan pengaruh dari luar, memerlukan profesi advokat yang bebas, bertanggungjawab, dan 
mandiri dalam menciptakan suatu peradilan adil, jujur, dan memiliki kepastian hukum bagi semua pencari keadilan dalam menegakkan hukum, keadilan, kebenaran, dan HAM. Berdasarkan Pasal 1 ayat (1) UndangUndang Advokat ditetapkan bahwa Advokat adalah orang yang berprofesi memberi jasa hukum, baik di dalam maupun di luar pengadilan yang memenuhi persyaratan berdasarkan ketentuan pada undang-undang ini, dan pada ayat (2) telah ditetapkan pula bahwasanya jasa hukum adalah jasa yang diberikan advokat berupa memberikan konsultasi hukum, dan bantuan hukum, menjalankan kuasa, mewakili, membela, mendampingi, dan melakukan tindakan hukum lain untuk kepentingan hukum klien.

Pengawasan kepada advokat dilakukan oleh organisasi advokat yang bernama PERADI. Pengawasan yang dilakukan organisasi advokat tersebut mempunyai tujuan agar advokat tersebut dalam menjalankan profesinya harus menjungjung tinggi kode etik profesi advokat dan peraturan perundang-undangan yang berlaku. Dalam pelaksanaannya pengawasan sehari-hari dilakukan oleh komisi pengawas yang telah dibentuk oleh organisasi advokat PERADI. Keanggotaan dari komisi pengawas tersebut terdiri atas unsur advokat senior, masyarakat, dan para ahli / akademisi. Tata cara mengenai pengawasan telah diatur lebih lanjut melalui keputusan organisasi advokat.
Advokat dalam melaksanakan profesinya sudah tentu memiliki hak dan kewajiban. Istilah hak tentunya tidaklah merupakan hal yang asing dalam dunia ilmu hukum. Secara umum hak dapat diartikan menjadi segala sesuatu yang harus diperoleh. Menentukan bahwa hak merupakan benar adanya, sehingga kekuasaan untuk menuntut sesuatu karena telah ditentukan oleh peraturan perundangundangan dan sebagainya, kekuasaan yang memang benar atas sesuatu atau agar menuntut sesuatu, derajat, dan martabat. Mengenai pengertian hak pendapat penulis adalah kekuasaan yang harus diraih oleh seseorang dalam mendapatkan atau berbuat sesuatu. Apabila menjalankan hak tidak sejalan dengan tujuannya hal itu dinamakan penyalahgunaan hak.

Pengertian dari istilah kewajiban secara umum dapat diartikan sebagai segala sesuatu yang harus dilakukan setelah/sebelum mendapatkan hak. Kewajiban adalah sesuatu yang wajib dilaksanakan, dilakukan, sebuah keharusan untuk melaksanakan suatu tugas pekerjaan perintah. Telah dijelaskan bahwa advokat dalam melaksanakan profesinya memiliki hak dan kewajiban yang telah diatur dalam Undang-Undang Advokat adalah sebagai berikut :

1. Menurut Pasal 14 menetapkan bahwa Advokat bebas dalam mengeluarkan pendapat atau pernyataan saat membela perkara yang menjadi tanggung jawabnya 
di dalam sidang Pengadilan dengan tetap berpegang teguh pada kode etik profesi, dan undang-undangan.

2. Menurut Pasal 15 telah menetapkan bahwa Advokat bebas dalam melaksanakan tugas dan profesinya dalam membela perkara yang menjadi tanggung jawabnya dengan tetap berpegang teguh pada kode etik profesi, dan undang-undangan.

3. Menurut Pasal 16 UndangUndang Advokat tidak dapat dituntut baik secara perdata maupun pidana dalam melaksanakan tugas dan profesinya dengan itikad baik untuk kepentingan pembelaan klien dalam sidang Pengadilan.

4. Menurut Pasal 17 telah menetapkan bahwa Advokat berhak mendapatkan informasi, dokumen, dan data lainnya, baik dari instansi Pemerintah maupun pihak lain yang berkaitan dengan kepentingan tersebut yang diperlukan dalam pembelaan kepentingan kliennya yang telah sesuai peraturan perundangundangan.

5. Menurut Pasal 19 ayat (2) menetapkan bahwa Advokat berhak atas kerahasiaannya dari hubungannya dengan klien, termasuk melindungi berkas dan dokumennya terhadap pemeriksaan atau penyitaan dan perlindungan terhadap penyadapan atas komunikasi elektronik Advokat.

6. Menurut Pasal 21 menetapkan bahwa Advokatberhakmenerima honor atas jasa hukum yang sudah diberikan kepada kliennya, yang ditetapkan dengan wajar berdasarkan persetujuan kedua belah pihak.

Kewajiban Advokat dalam Undang-Undang Advokat adalah sebagai berikut:

1. Menurut Pasal 18 ayat (1) menetapkan bahwa Advokat dalam melaksanakan tugas dan profesinyadilarang membedakan perlakuan terhadap klien berdasarkan, agama, politik, jenis kelamin, ras, keturunan, atau latar belakang budaya, dan sosial.

2. Menurut Pasal 19 ayat (1) menetapkan bahwa Advokat wajib merahasiakan segala sesuatu yang telah diketahuinya atau diperolehnya dari kliennya karena hubungan profesinya, kecuali ditentukan lain oleh perundang-undangan.

3. Menurut Pasal 20 ayat (1) menetapkan bahwa Advokat dilarang memegang jabatan lain yang bertentangan dengan kepentingan tugas dan martabat profesinya.

4. Menurut Pasal 20 ayat (2) menetapkan bahwa Advokat dilarang memiliki jabatan lain yang meminta pengabdian sedemikian rupa hingga 
merugikan profesi Advokat atau mengurangi kebebasan dan kemerdekaan dalam melaksanakan tugas dan profesinya.

5. Menurut Pasal 20 ayat (3) telah menetapkan bahwa Advokat yang menjadi pejabat negara, tidak dapat melaksanakan tugas dan profesi Advokat selama menjabat jabatan tersebut.

6. Menurut Pasal 22 ayat (1) telah menetapkan bahwa Advokat wajib memberikan bantuan hukum secara gratis kepada pencari keadilan yang kurang mampu.

7. Menurut Pasal 26 ayat (2) menetapkan bahwa Advokat wajib tunduk dan mematuhi ketentuan tentang Dewan Kehormatan Organisasi Advokat dan kode etik profesi Advokat.

Kondisi advokat ataupun konsultan hukum asing di Negara Indonesia pada intinya tidaklah dilarang, akan tetapi berdasarkan apa yang telah ditetapkan oleh Pasal 23 Undang-Undang Advokat No. 18 Tahun 2003, telah dibatasi hanya pada kewenangan dalam memberikan nasihat ataupun pendapat hukum yang hubungannya dengan hukum asing. Kehadiran advokat asing di Indonesia, dibatasi dalam kedudukannya sebagai karyawan ataupun tenaga ahli di suatu kantor advokat Indonesia. Advokat ataupun konsultan hukum asing tidak diperkenankan beracara di pengadilan
Negara Republik Indonesia ataupun memberikan nasihat dan atau pendapat hukum (legal service) berdasarkan hukum di Indonesia, serta tidak diperkenankan berpraktek secara langsung atau membuka kantor jasa hukum di Indonesia.

Dengan adanya aturan yang telah ditetapkan pada Pasal 23 Undang-Undang Advokat tersebut pada kenyataannya sudah tidak dapat lagi ditegakkan, secara khusus dalam hal kehadiran dan praktek dari para advokat asing di Indonesia, dengan alasan yaitu :

1. Pemberian bantuan hukum maupun pendapat hukum pada pelaku usaha (investor asing) bisa dilaksanakan pada pemberian jasa hukum yang bersifat sementara, sehingga advokat ataupun konsultan hukum asing dapat melakukan pekerjaannya tersebut di Indonesia tanpa harus tinggal di Indonesia. Dengan kata lain, advokat asing tersebut, datang ke Indonesia pagi hari dan sore ataupun keesokan harinya telah kembali lagi ke negara asalnya. Praktek yang demikian akan sangat sulit dideteksi, kecuali ada pihak lain yang secara sengaja melaporkan tindakan pemberian jasa hukum oleh advokat asing tersebut yang telah melanggar ketentuan Pasal 23 Undang-Undang Advokat tersebut. 
2. Akibatmodernisasiteknologidan komunikasidapatmengakibatkan tidak adanya lagi jarak diantara wilayah, sehingga pemberian jasa hukum oleh advokat asing dapat dilakukan melalui penggunaan alat telekomunikasi yang canggih, misalnya rapat secara online, ataupun dengan aplikasi skype.

3. Maksud dari tidak dapatnya advokat asing berpraktek secara langsung, dan tidak dapat membuka perwakilannya di Negara Republik Indonesia bagi advokat asing, sangat kabur pengertian bila dihadapkan dengan fakta-fakta yang telah ada dansudahlamahadirdi Indonesia, dimana merger (penggabungan) dari lawyer-lawyer asing dengan lawyer-lawyer yang berkantor hukum Indonesia, dan hal tersebut hanya terlihat seakanakan adalah hubungan pemberi kerja dengan pekerja ataupun tenaga ahli (employers dengan employees ataupun foreign legal expert) tetapi hal tersebut dapat diketahui atau "tercium" sebagai hubungan partnership, bahkan ada yang telah secara terangterangan menggunakan kata "in association with advokat asing. "

Kode etik dari suatu profesi adalah produk etika terapan karena dihasilkan berdasar penerapan pemikiran etis atas suatu profesi. Kode etik merupakan bagian dari hukum positif tertulis tetapi tidak mempunyai sanksi yang keras, berlakunya kode etik semata-mata berdasarkan kesadaran moral anggota profesi. Menurut Sumaryono kode etik perlu dirumuskan secara tertulis disebabkan karena tiga hal, yaitu: ${ }^{12}$

1. Sebagai pencegah kesalah pahaman dan konflik.

2. Sebagai pencegah campur tangan pihak lain dalam permasalahan intern;

3. Sebagai sarana kontrol sosial;

Adanya aturan yang mengatur kode etik advokat membuat PERADI merupakan organisasi advokat yang memberikan rekomendasi terhadap lawyer-lawyer asing yang akan bekerja di kantor-kantor hukum di Indonesia, telah memberikan upaya untuk menertibkan keberadaan dan aktivitas dari advokat asing dengan memberi penekanan pada maksud dari Pasal 24 Undang-Undang Advokat dalam menentukan tunduknya Advokat Asing terhadap aturan kode etik Advokat Indonesia dan aturan hukum yang berlaku di Indonesia, dengan cara mewajibkan seluruh advokat asing, baik yang akan bekerja di Indonesia, maupun advokatadvokat asing yang telah bekerja di kantor-kantor hukum Indonesia, untuk wajib mengikuti pendidikan kode etik advokat Indonesia, serta mengikuti ujian dan lulus dari ujian tertulis

12 E. Sumaryono, 1995, Etika Profesi Hukum: Norma-norma bagi Penegak Hukum, Kanisius, Yogyakarta, hlm. 35. 
yang dilaksanakan oleh PERADI dalam bahasa Inggris. Advokatadvokat asing yang tidak lulus, tidak akan mendapatkan rekomendasi dari PERADI untuk dapat bekerja dan melanjutkan status kerjanya di Indonesia. Advokat-advokat asing yang telah lulus dari ujian kodek etik advokat Indonesia tersebut, PERADI mewajibkan advokat asing tersebut agar dapat menyatakan kesiapannya dalam memberikan jasa hukum secara gratis untuk waktu minimum sebanyak 30 jam setiap tahunnya. Hal tersebut diatas akan dapat memberikan akses yang lebih kuat pada PERADI untuk dapat mengontrol langkah dan perilaku dari advokat-advokat asing yang telah mendapatkan ijin untuk berpraktek di Negara Republik Indonesia, agar memenuhi seluruh ketentuan yang diatur dalam kode etik advokat Indonesia dan juga kewenangannya untuk memberikan sanksi hukum terhadap advokat-advokat asing yang melakukan pelanggaran ketentuanketentuan tersebut, sama seperti sanksisanksi yang dijatuhkan pada advokatadvokat Indonesia yang melakukan pelanggaran hukum dan kodek etik.

Dalam pertemuan-pertemuan internasional yang dihadiri oleh PERADI, secara tegas peradi telah menjelaskan sikap Indonesia terhadap aktivitas advokat asing sejalan dengan keberadaan Pasal 23 Undang-Undang Advokat, dan kewajiban kedudukan dari advokat-advokat asing yang akan bekerja di Indonesia terhadap Kode etik advokat Indonesia serta ketentuan-ketentuan hukum yang berlaku, termasuk pada kewajiban untuk memberikan jasa hukum secara cuma-cuma.

PERADI juga telah meminta partisipasi dari beberapa advokat asing untuk membantu PERADI dalam kepanitiaan Internasional dan dalam misi menjelaskan perkembanganperkembangan hukum Indonesia di dunia Internasional. Proses perkembangan hukum dari suatu negara akan sangat sulit terlepas dari komitmen-komitmen internasional yang telah disepakatinya. Dalam hubungannya dengan pelaksanaan AEC, perkembangan komitmen dari 10 kepala negara anggota ASEAN akan sangat menentukan perkembangan hukum selanjutnya dari masing-masing negara anggota ASEAN tersebut, termasuk pada target pelaksanaan liberalisasi profesi dan jasa hukum di ASEAN. Dengan pengertian lain, persetujuan Indonesia terhadap ASEAN Vision 2020, dan juga The ASEAN Blueprint serta the ASEAN Comprehensive Investment Agreement yang seluruhnya telah mewacanakan arah pembebasan seluruh restriksi sehubungan dengan pemberian dan perdagangan dalam bidang jasa, akan secara pasti menuju pada pembangunan komitmen bersama liberalisasi dari profesi advokat danjasa hukum di wilayah ASEAN, dimana bila hal tersebut telah tiba, maka akan sangat mempengaruhi pembatasanpembatasan terhadap advokat ataupun 
konsultan asing yang telah diatur dalam Pasal 23 Undang-Undang Advokat, atau paling tidak pada hak-hak mereka untuk dapat membuka praktek ataupun perwakilan di Indonesia.

Hal-hal tersebut di atas memberikan suatu pemahaman bahwa, cepat atau lambat akan terjadi liberalisasi pemberian jasa hukum dan aktivitas advokat di AEC. Sehingga, menyadari hal tersebut, advokatadvokat Indonesia haruslah, tidak lagi terperangkap pada suatu kekhawatirankekhawatiran akan semakin bebasnya advokat asing beraktivitas di Indonesia, akan tetapi suka atau tidak suka, harus telah memutar haluan berfikir dan arah visi pada suatu langkah aksi, yaitu mempersiapkan diri sebaik mungkin dalam menghadapi pasar ASEAN.

Bersaing secara kualitas dan ataupun bekerja sama secara setara dengan advokat-advokat asing dalam memberikan jasa hukum pada aktivitas-aktivitas komersial yang semakin shopisticated dan detail serta semakin memiliki korelasi ataupun aspek internasional, tidak saja dalam wilayah Republik Indonesia, akan tetapi pada wilayah ASEAN. Peluang pada advokat-advokat Indonesia untuk dapat berpraktek dan memberikan jasa hukum di masing-masing dari 10 negara anggota ASEAN dan juga negara-negara mitra strategi lainnya sebenarnya akan menumbuh kembangkan wilayah pelayanan dan hubungan dari advokat-advokat Indonesia pada level global dan juga pelaku-pelaku pasar dan investor serta pemilik-pemilik modal global (first source of clients), termasuk juga perolehan income dari pasar ASEAN yang begitu besar. Hal ini tidak semudah membalikkan telapak tangan, apalagi bahasa inggris yang menjadi syarat dasar dari pembangunan kemampuan dan kesiapan tersebut, masih merupakan "barang mewah" bagi kebanyakan advokat di Indonesia. Istilah mempersiapkan diri, tentunya termasuk pada tekad untuk memiliki kemampuan pada penguasaan minimal bahasa dunia tersebut, termasuk pada mempersiapkan generasi-generasi advokat melalui kurikulum-kurikulum yang dipersiapkan secara sungguhsungguh oleh universitas-universitas di Indonesia.

\section{KESIMPULAN}

Bahwa dengan adanya larangan terhadap Advokat Asing untuk beracara di Peradilan Indonesia dengan kesepakatan Internasional GATS, dan hal ini tercantum di dalam Undang-Undang No. 18 Tahun 2003 tentang advokat dalam Pasal 23 Undang-Undang Advokat diatur bahwa advokat asing dilarang beracara di sidang pengadilan, berpraktek dan/ atau membuka kantor jasa hukum atau perwakilannya di Indonesia. Advokat asing dapat dipekerjakan oleh kantor advokat (domestik) sebagai karyawan atau tenaga ahli dalam bidang hukum asing atas izin Pemerintah dengan rekomendasi Organisasi 
Advokat dengan disertai pembebanan kewajiban untuk memberikan jasa hukum secara cuma-cuma untuk suatu waktu tertentu kepada dunia pendidikan dan penelitian hukum. Adapun peraturan pelaksanaan secara komprehensif mengenai persyaratan dan tata cara mempekerjakan advokat asing serta kewajiban memberikan jasa hukum secara cuma-cuma kepada dunia pendidikan dan penelitian hukum saat ini diatur lebih lanjut berdasarkan Kepmenkumham RI Nomor M.11-HT.04.02 Tahun 2004. Dengan konstruksi hukum semacam ini maka advokat asing secara tegas dilarang untuk berpraktik dan/atau membuka kantor jasa hukum atau perwakilannya di Indonesia. Hal ini pada prinsipnya tidaklah bertentangan dengan pedoman International Bar Association (IBA), namun demikian tiap-tiap negara memiliki regulasinya masing-masing terkait advokat asing. Amerika Serikat misalnya mengatur bahwa advokat asing dari negara lain dapat berpraktik di Amerika Serikat apabila telah lulus dari ujian bar exam dan sama sekali tidak ada ketentuan di Amerika Serikat yang mengatur bahwa advokat yang berpraktik di Amerika Serikat haruslah berkewarganegaraan Amerika Serikat. Bahwa hak dan kewajiban seorang advokat asing dalam Undang-Undang Advocat sebenarnya sama dengan advocat lokal di Negara Indonesia akan tetapi advokat asing mempunyai batasan-batasan dalam melaksanakan profesinya, batasan tersebut adalah tidak diperkenankanya advokat asing untuk dapat beracara di Peradilan Indonesia sesuai Pasal 23 UndangUndang No. 18 tahun 2003 tentang Advokat.

\section{DAFTAR PUSTAKA}

Bernard, M Hoekman dan Michel Koestecki, 1995, The Political Economy of thr word Trading System From Gatt to WTO, oxford, oxford university press.

Dirjen Kerja Sama ASEAN Kementerian Luar Negeri Republik Indonesia,2009, Integrasi Ekonomi ASEAN dibidang Jasa, Jakarta.

Syahmin A.K, 2006, Hukum Dagang Internasional (Dalam Kerangka Studi Analitis), PT. Raja Grafindo Persada, Jakarta.

Soerjono Soekanto, 2006, Penelitian

Hukum Normatif(Suatu Tinjauan

Singkat), PT Grafindo Persada, Jakarta.

Sumaryono, 1995, Etika Profesi

Hukum: Norma-norma bagi Penegak Hukum, Kanisius, Yogyakarta.

Philipus M.Hadjon,2007,Perlindungan Hukum Bagi Rakyat Indonesia, PT Bina Ilmu, Surabaya.

Zainudin, H, 2011, Metode Penelitian

Hukum, Sinar Grafika, Jakarta.

\section{Jurnal:}

Ananta,MaharaniRoya."IMPLEMENTASIKEWAJIBANADVOKAT DALAM MENJAGA 
RAHASIA KLIEN (Studi di Kantor Advokat Jonifianto \& Partners, Lardi \& Partners, dan Kantor Sekretariat Dewan Kehormatan Daerah (DKD) PERADI Jawa Timur)." Jurnal Mahasiswa Fakultas Hukum 1.2 ( 201014 ). < h t tp: // hu kum. studentjournal.ub.ac.id/index. php/hukum/article/view/370>. diakses tanggal 14 april 2017.

Delarosa, Stella. "Liberalisasi Fee Advokat: Antara Perlindungan Dan Kompetisi Terhadap Advokat Indonesia." Veritas et Justitia 2.2 (2016): 355. $<$ http://journal.unpar.ac.id/ index.php/veritas/article/ view/2271> diakses tanggal 14 april 2017. doi: <http://dx.doi. org/10.25123/vej.22.

Sari, I Made. PERSAMAAN PERLAKUAN PARA PIHAK DALAM BERACARA DI KPPU DALAM PERSPEKTIF HUKUMACARAPERADILAN INDONESIA. Jurnal Magister Hukum Udayana (Udayana Master Law Journal), vol. 5 no. 2 edisi juli 2016. <https:// ojs.unud.ac.id/index.php/jmhu/ article/view/22434>. Diakses tanggal 14 april 2017. doi: <https://doi.org/10.24843/ JMHU.2016.v05.i02.p12.

\section{Peraturan Perundang-undangan:}

Undang-Undang Negara Kesatuan Republik Indonesia Tahun 1945.

Undang-Undang No. 18 Tahun 2003 tentang Advokat (Lembaran Negara No. 49 Tahun 2003 dan Tambahan Lembaran Negara No. 4288).

Undang-Undang No. 7 Tahun 1974 tentang Persetujuan Pembentukan Organisasi Perdagangan Dunia (Lembaran Negara No. 57 Tahun 1994 dan Tambahan Lembaran Negara No. 3564). 